\title{
Molecular Characterization of Orchid Variants Spathoglottis plicata Blume Based on RAPD Analysis
}

\author{
Suyitno Aloysius ${ }^{1}$, Ixora S. Mercuriani ${ }^{1}$, Ratnawati ${ }^{1}$ and Sudarsono ${ }^{1}$ \\ ${ }^{1}$ Lecturer in the Department of Biology Education, Faculty of Mathematics and Natural Sciences, Yogyakarta State \\ University \\ *Corresponding author. Email: suyitno_al@uny.ac.id
}

\begin{abstract}
The development of $S$. plicata orchid variants is important to increase their genetic diversity. This study aims to determine the genetic diversity of $S$. plicata orchid variants based on RAPD analysis. The research sample was 15 plant variants consisting of wild type and mutant orchid variants. Molecular characterization was used to identify the genetic diversity of orchid variants based on the PCR-RAPD using eight universal primers from the screening results. The DNA amplicon electropherogram from RAPD results was converted to binary data and analyzed with GenAlex 6.1 to obtain the genetic distance, scatter diagram, and the percentage of DNA polymorphism. The data were also analyzed using NTSYS ver.2.2 to obtain a dendrogram cluster using the Unweighted Pair-Group Method using Arithmetic Average (UPGMA). The results showed that DNA polymorphism was found in the wild-type and mutant orchid variants. The percentage of DNA polymorphism of mutant orchid groups was greater than that of wild type orchids. The results of the Principal Coordinate Analysis based on the genetic distance showed that the S. plicata mutant orchid variant was in a different quadrant from the wild type group. Based on the dendrogram cluster, the mutant orchid variants were located away from the wild orchid, which confirmed that the mutant orchid variants have undergone genetic changes.
\end{abstract}

Keywords: Spathoglottis plicata variants, genetic diversity, RAPD.

\section{INTRODUCTION}

Spathoglottis plicata orchid is a significant commodity with a high economic value, especially for orchids with unique characters and beautiful flowers. Spathoglottis orchids with purple flowers are the most common species found. This happens because most orchid propagation is carried out by splitting pseudobulb or tillers. Morphologically, the orchid variation can be observed from the characteristics of the leaf length, plant height, number of tillers, flower stalk length, and flower color. Another type of Spathoglottis orchid found is Spathoglottis with yellow and white flowers. In addition to conservation, the development of this orchid variant also needs to be improved. For this reason, morphological and molecular characterization is important for all variants found to determine their conservation and development strategies.

Spathoglottis orchid is one of the best-selling ornamental orchid plants. Many orchid fans and growers have collected this orchid. This plant is easily cultivated only by splitting the pseudobulb, but such reproduction will only produce clones and not produce variants. In some countries, this plant is reportedly vulnerable to extinction. The status of this orchid is not stated in the red list plant at IUCN (International Union for Conservation of Nature), but it is declared as a vulnerable plant in Australia [1] and India [2]. There are three challenges associated with the reproduction of orchid plants, including the preservation of orchid species to avoid extinction, the development of clones with certain superior characters, and the creation of variants with new characters. The development of diversity will increase the economic value of these orchids as commodity plants. Variants with superior morphological characters are found on the habitus profile, color and number of flowers, and the length of the stems, which is proportional to the plant height. Orchids that are not too short or too long have interesting characters [3].

Based on previous research [4], it was reported that one of the 118 wild type orchids found in the Yogyakarta Region was $S$. plicata. From the results of in vitro culture, the orchid variant obtained was $S$. plicata with purple, purplish, or white flowers [5]. The 
question is whether morphological variation in orchid variants is related to the genetic variation, which is an interesting problem to observe. Molecular variations can be detected by DNA, RNA, or protein analysis [6]. One of the most widely used molecular characterization methods is a DNA analysis using RAPD (Random Amplification of Polymorphic DNA) markers. The research aims were to identify the genetic variability of S. plicata variant plants based on the RAPD analysis.

\section{RESEARCH METHOD}

\subsection{Research material}

The research material is about 30 months old variants of $S$. plicata Blume orchid, consisting of wild type and mutant variants derived from in vitro seed culture. Cultured seeds come from the normal seeds and seeds irradiated with X-rays.

\subsection{DNA isolation}

The DNA analyzed was genome DNA from the wild type orchids and S. plicata variant taken from small pieces of leaves. The DNA isolation was carried out by the CTAB method, according to Murray and Tompson [7], with modification. The DNA quantification was performed by spectrophotometry at $\lambda 260$ and $280 \mathrm{~nm}$ to determine the concentration and purity of the isolated DNA.

\subsection{DNA analysis with RAPD}

Molecular analysis (DNA) was performed by PCRRAPD method (Polymerase Chain Reaction - Random Amplified Polymorphism DNA) [8]. It was used to detect DNA polymorphisms to determine the level of genetic diversity (DNA) in the wild-type orchid and mutant variants. The molecular markers used for PCRRAPD were determined based on the results of screening 22 universal primers using three DNA genome samples. The screening results obtained nine primers (Table 1)which showed the presence of DNA polymorphism

Table 1. Selected universal primers of DNA analysis with PCR-RAPD

\begin{tabular}{|l|l|c|}
\hline N0 & Primer & $\begin{array}{c}\text { Nucleotide sequence } \\
5^{\prime}-3^{\prime}\end{array}$ \\
\hline 1 & OPA-02 & TGCCGAGCTG \\
\hline 2 & OPA-11 & CAATCGCCGT \\
\hline 3 & OPA-12 & TCGGCGATAG \\
\hline 4 & OPA-14 & TCTGTGCTGG \\
\hline 5 & OPB-1 & GTTTCGCTCC \\
\hline 6 & OPB-4 & GGACTGGAGT \\
\hline 7 & OPD-12 & CACCGTATCC \\
\hline 8 & OPD-14 & CTTCCCCAAG \\
\hline
\end{tabular}

The PCR reaction was carried out using a $200 \mu \mathrm{L}$ PCR microtube with a final volume of $10 \mu \mathrm{L}$, containing $5 \mu \mathrm{L}$ of Go Taq Green (Promega), $0.25 \mu \mathrm{L}(10 \mu \mathrm{M})$ primer (decamer), $2.5 \mu \mathrm{L}$ DNA template (diluted $25 \mathrm{x}$ ), and $2.25 \mu \mathrm{L}$ nuclease free water. PCR was performed in stages: pre-denaturation ( $94 \mathrm{o} \mathrm{C}, 1$ minute), denaturation (94o C, 30 seconds), annealing (37o C, 30 seconds), elongation (72o C, 1 minute $30 \mathrm{sec})$, expansion $(72 \mathrm{o} \mathrm{C}$, 7 minutes), and hold (4o C, 5 minutes). In addition, $\mathrm{PCR}$ is run in 45 cycles.

The DNA amplicon from the PCR was then visualized by electrophoresis on $1.5 \%$ agarose gel with $1 \mu \mathrm{L}$ of DNA staining (FloroSafe). The DNA size marker used is $1 \mathrm{~kb}$ DNA Ladder Vivantis, which provides variations in the size of DNA fragments between 100-10,000 bp. Electrophoresis was carried out in a $1 \mathrm{x}$ TBE solution with 100 volts in 55 minutes. The electrophoresis gel was then observed under UV and photographed with a digital camera

\subsection{Data processing}

The DNA amplicon electropherogram from RAPD results is converted into binary data by giving a score of 1 if there is a DNA band, and a zero score if there is no DNA band. The data were then analyzed using the GenAlex 6.1 program [9] to obtain genetic distance, scatter diagram, and percentage of DNA polymorphism. The data were then analyzed using the NTSYS version 2.2 program to obtain dendrogram clusters [10], using the UPGMA (Unweighted Pair Group Methods with Arithmetic Averages) method. 


\section{RESULT AND DISCISSION}

\subsection{DNA analysis with RAPD}

The collection of $S$. plicata orchid variants is derived from the results of in vitro culture of normal and irradiated seeds. The $S$. plicata orchid has a variety of morphological characters, especially in terms of flower size and color, including its labellum character (Figure 1). Other morphological variations appear in the leaf length, flower stalk length, plant height, clump size, or the number of tillers (Figure 2). This morphological variation is likely related to genetic variation.

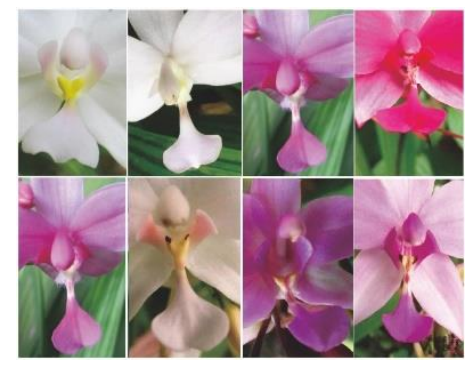

Figure 1: Flower color variations on several $S$. plicata orchid variants

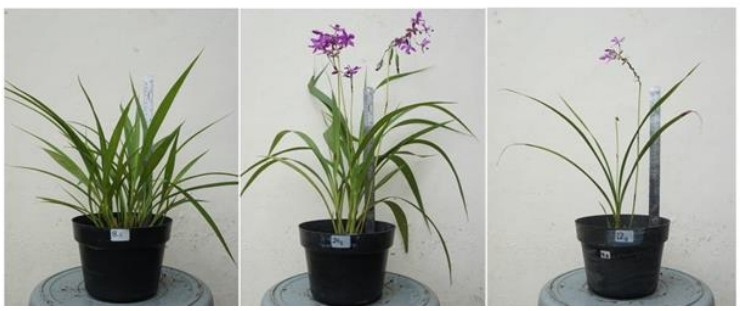

Figure 2: Differences in morphology of several S. plicata orchid variants; Ruler size $=40 \mathrm{~cm}$

Variations of flowers in S. plicata were found in both wild type and mutants Variations in the wild type orchid are due to genetic recombination. According to Soraka \& Lyakh [11], plant mutations can occur in various organs, including mutations of leaves, stems, roots, flowers, fruits, and seeds. The results of X-ray irradiation on $S$. plicata seeds also produce phenotypic variations in leaves, roots, and stems; and induce premature flowering of mutant seedlings in bottles [12].
Romeida et al. [13] also found albino mutants, purple stem mutants, variegated mutants, and flower color mutants in S. plicata derived from orchid pods radiated with gamma rays.

\subsection{DNA analysis with RAPD}

The DNA analysis results using RAPD markers on $15 \mathrm{~S}$. plicata variant samples showed variations or differences in DNA band patterns (Figure 3). The number of DNA bands and DNA polymorphisms produced from RAPD using 8 primers showed a wide variation. Most primers produced polymorphisms of 60 $100 \%$, except for the OPB 1 primer.
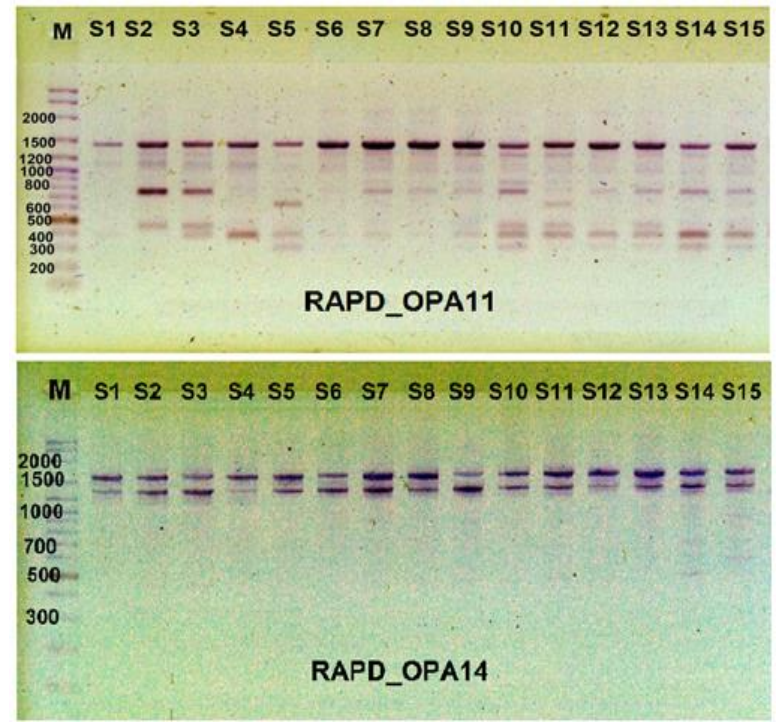

Figure 3: DNA electropherogram of S. plicata orchid variants from PCR RAPD with OPA-11 \& OPA14 primers

Based on the results of the RAPD analysis, genomic DNA samples from the $S$. plicata orchid variant produced 3-12 DNA bands with a percentage of polymorphism reaching $90-100 \%$ (Table 2). This indicates that the primers are able to strongly demonstrate DNA polymorphism in the S.plicata orchid variants. Variations or differences between the variants can also be seen from the genetic dsitance (Table 3 ). 
Table 2: Number of DNA bands and DNA polymorphism percentage produced by the primer

\begin{tabular}{|l|l|c|c|c|c|}
\hline \multicolumn{1}{|c|}{ Primer } & $\begin{array}{c}\text { Nucleotide } \\
\text { sequence }\end{array}$ & $\begin{array}{c}\text { Total } \\
\text { band }\end{array}$ & $\begin{array}{c}\text { Number of } \\
\text { polymorphism }\end{array}$ & $\begin{array}{c}\text { Number of } \\
\text { monomorphism }\end{array}$ & $\begin{array}{c}\text { Polymor- } \\
\text { phisme (\%) }\end{array}$ \\
\hline OPA-02 & TGCCGAGCTG & 9 & 9 & 0 & 100 \\
\hline OPA-11 & CAATCGCCGT & 10 & 9 & 1 & 90 \\
\hline OPA-12 & TCGGCGATAG & 7 & 7 & 0 & 100 \\
\hline OPA-14 & TCTGTGCTGG & 5 & 3 & 0 & 60 \\
\hline OPB-1 & GTTTCGCTCC & 4 & 4 & 1 & 100 \\
\hline OPB-4 & GGACTGGAGT & 1 & 0 & 0 & 100 \\
\hline OPD-12 & CACCGTATCC & 12 & 12 & 0 & 100 \\
\hline OPD-14 & CTTCCCCAAG & 8 & 8 & & 0 \\
\hline
\end{tabular}

Table 3. Genetic Distance Matrix of $15 \mathrm{~S}$. plicata Variants

\begin{tabular}{|c|c|c|c|c|c|c|c|c|c|c|c|c|c|c|c|}
\hline S1 & S2 & S3 & S4 & S5 & S6 & S7 & S8 & S9 & S10 & S11 & S12 & S13 & S14 & S15 & \\
\hline $\mathbf{0}$ & & & & & & & & & & & & & & & S1 \\
\hline 6 & $\mathbf{0}$ & & & & & & & & & & & & & & S2 \\
\hline 9 & 7 & $\mathbf{0}$ & & & & & & & & & & & & & S3 \\
\hline 12 & 16 & 17 & $\mathbf{0}$ & & & & & & & & & & & & S4 \\
\hline 15 & 17 & 20 & 7 & $\mathbf{0}$ & & & & & & & & & & & S5 \\
\hline 14 & 16 & 19 & 4 & 3 & $\mathbf{0}$ & & & & & & & & & & S6 \\
\hline 13 & 15 & 18 & 13 & 12 & 11 & $\mathbf{0}$ & & & & & & & & & S7 \\
\hline 17 & 19 & 20 & 13 & 12 & 11 & 8 & $\mathbf{0}$ & & & & & & & & S8 \\
\hline 17 & 19 & 22 & 13 & 10 & 9 & 6 & 8 & 0 & & & & & & & S9 \\
\hline 22 & 24 & 27 & 16 & 15 & 14 & 9 & 13 & 9 & 0 & & & & & & S10 \\
\hline 22 & 24 & 23 & 14 & 13 & 12 & 15 & 13 & 9 & 14 & 0 & & & & & S11 \\
\hline 24 & 26 & 29 & 16 & 17 & 14 & 15 & 19 & 15 & 14 & 18 & $\mathbf{0}$ & & & & S12 \\
\hline 19 & 21 & 24 & 15 & 10 & 11 & 8 & 10 & 8 & 9 & 13 & 13 & $\mathbf{0}$ & & & S13 \\
\hline 23 & 25 & 26 & 19 & 16 & 17 & 14 & 14 & 12 & 13 & 15 & 21 & 14 & 0 & & S14 \\
\hline 22 & 24 & 25 & 14 & 13 & 14 & 15 & 13 & 15 & 16 & 14 & 18 & 13 & 15 & 0 & S15 \\
\hline
\end{tabular}

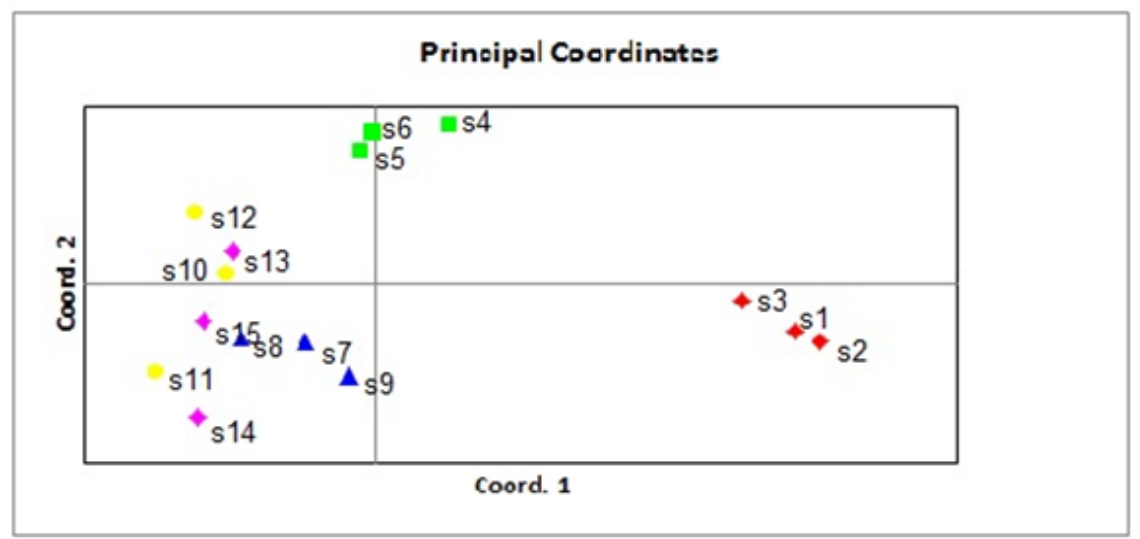

Figure 4. Scattered Diagram Based on Principal Coordinat Analysis of Genetic Distance of S. plicata Orchid Variants 


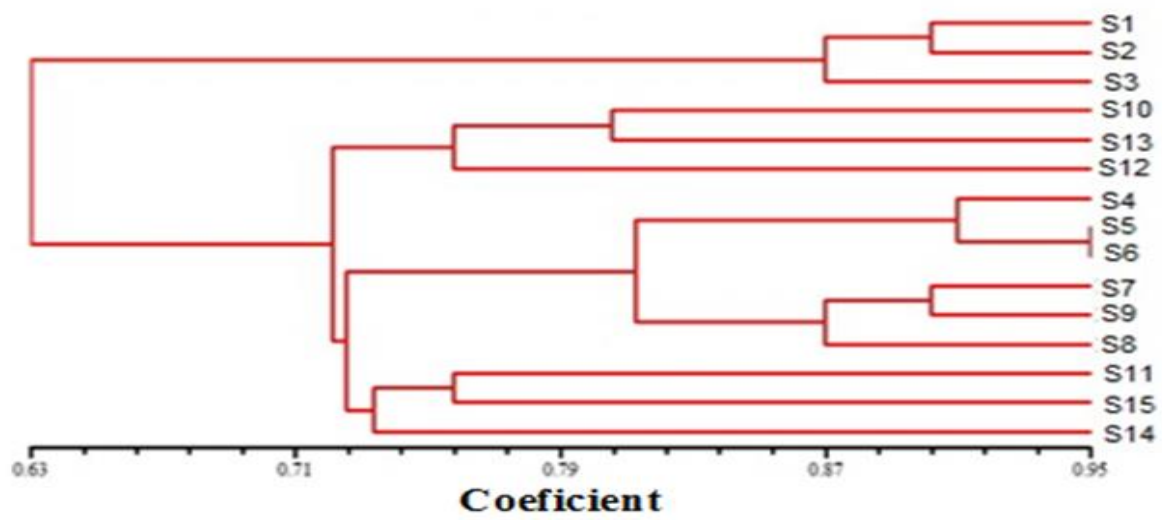

Figure 5. Dendrogram Cluster Based on Genetic Distance of 15 S. plicata Orchid Variants

Regarding the Principal Coordinate Analysis (PCA) of the GenAlex ver 6.1 program (Figure 4), the wildtype $S$. plicata variants are clustered in the same quadrant, whereas groups of the mutant variants are scattered in the opposite quadrants.

The molecular character of $S$. plicata orchid consisting of wild type variants $\mathrm{S} 1, \mathrm{~S} 2$, and $\mathrm{S} 3 \mathrm{had}$ a very high similarity index that reached 0.87 or had a very high level of similarity of $87 \%$ (Figure 5). The PCA analysis results showed that these wild type orchid variants cluster in the same quadrant (Figure 4). In contrast, the mutant variants had a lower similarity index $(<0.64)$ than that of the wild type variants. Mutant plant variants were scattered in different quadrants. Among the 12 mutant $S$. plicata orchid variants, some of them have a large genetic distance (Figure 5). This gave an indication that several plants had undergone significant genetic changes, as indicated by a higher percentage of DNA polymorphisms. Nonetheless, the differences due to DNA changes in the mutant group did not show any effects on the morphology of the plants.

The appearance of morphological variations due to gamma-ray radiation was also found in roses [14]. Morphological changes due to radiation also occur in Gypsophila paniculata [15] and Moluccella laevis [16]. Based on the results of the DNA analysis of homologous POH1 [5], X-ray irradiation resulted in insertion, deletion, and substitution of DNA nucleotides in S. plicata orchids that experience shoot mutations. Rick [17] reported the occurrence of chromosomal aberrations, namely ring deletion in the Tradescantia pollen due to X-ray irradiation. Murata et al. [18] found mutation deletion and insertion of one or several nucleotides in the medicinal plant group of Angelica acutiloba in Japan. X-ray irradiation on S. plicata Blume seeds has been proven able to induce the prominent changes in morphology and genetics in S. plicata seeds so that it makes sense that the mutated orchids exhibit greater genetic variability than that of wild orchids.

\section{CONCLUSION}

Genetic variability was found in S. plicata orchid variants, both in wild type and in mutant variants. It was shown by the higher average percentage of DNA polymorphism; the more diffuse the distribution of variants in the scatter diagram, the greater the molecular similarity index in the dendrogram cluster. A higher percentage of DNA polymorphisms in the mutant variant group than in the wild type group indicates an increase in the genetic variability due to DNA changes. The similarity index of the mutant group is lower $(<0.64)$ than that of the wild type group (> 87\%), indicating that some variants of the mutant are potential to become new cultivars.

\section{ACKNOWLEDGMENTS}

The researchers would like to thank the Rector of YSU and Director of the Institute for Research and Community Service, YSU, for providing funds Daftar Isian Pelaksanaan Anggaran to support the research.

\section{REFERENCES}

[1] E.M. Clarke, E.A. Emerson, Design and synthesis of synchronization skeletons using branching time temporal logic, in: D. Kozen (Eds.), Workshop on Logics of Programs, Lecture Notes in Computer Science, vol. 131, Springer, Berlin, Heidelberg, 1981, pp. 52-71. DOI: https://doi.org/10.1007/ BFb0025774

[2] J.P. Queille, J. Sifakis, Specification and verification of concurrent systems in CESAR, in: M. Dezani-Ciancaglini and U. Montanari (Eds.), Proceedings of the 5th International Symposium on Programming, Lecture Notes in Computer Science, vol. 137, Springer, Berlin, Heidelberg, 1982, pp. 
337-351. DOI: https://doi.org/10.1007/3-540-11494$\underline{7} 22$

[3] C. Baier, J-P. Katoen, Principles of Model Checking, MIT Press, 2008.

M. Kwiatkowska, G. Norman, D. Parker, Stochastic model checking, in: M. Bernardo, J. Hillston (Eds.), Proceedings of the Formal Methods for the Design of Computer, Communication and Software Systems: Performance Evaluation (SFM), Springer, Berlin, Heidelberg, 2007, pp. 220-270. DOI: https://doi.org/10.1007/978-3-540-72522-0_6

[5] V. Forejt, M. Kwiatkowska, G. Norman, D. Parker, Automated verification techniques for probabilistic systems, in: M. Bernardo, V. Issarny (Eds.), Proceedings of the Formal Methods for Eternal Networked Software Systems (SFM), Springer, Berlin, Heidelberg, 2011, pp. 53-113. DOI: https://doi.org/10.1007/978-3-642-21455-4_3

[6] G.D. Penna, B. Intrigila, I. Melatti, E. Tronci, M.V. Zilli, Bounded probabilistic model checking with the muralpha verifier, in: A.J. Hu, A.K. Martin (Eds.), Proceedings of the Formal Methods in Computer-Aided Design, Springer, Berlin, Heidelberg, 2004, pp. 214-229. DOI: https://doi.org/10.1007/978-3-540-30494-4_16

[7] E. Clarke, O. Grumberg, S. Jha, et al., Counterexample-guided abstraction refinement, in: E.A. Emerson, A.P. Sistla (Eds.), Computer Aided Verification, Springer, Berlin, Heidelberg, 2000, pp. 154-169. DOI: https://doi.org/ 10.1007 /10722167_15

[8] H. Barringer, R. Kuiper, A. Pnueli, Now you may compose temporal logic specifications, in: Proceedings of the Sixteenth Annual ACM Symposium on the Theory of Computing (STOC), ACM, 1984, pp. 51-63. DOI: https://doi.org/10.1145/800057.808665 